\title{
Helsedirektoratet gir feil anbefaling om bestemmelse av fosteralder
}

\author{
I oktober 2014 kom Helsedirektoratet med en anbefaling om at hele landet skal bruke én ultralydmetode, \\ eSnurra, for bestemmelse av svangerskapsalder og termin. Vi mener at dette er en faglig uforsvarlig \\ anbefaling og at direktoratet har håndtert prosessen uryddig.
}

Høsten 2014 foregikk det en offentlig debatt om abortgrense og svangerskapsalder. Alderen kan bestemmes på flere måter, og ultralydmåling inngår som et viktig bidrag. I Norge er to metoder i bruk: Terminhjulet, som er utviklet i Bergen (Bergens-metoden) med deltakelse av flere av forfatterne av denne kommentarartikkelen, og eSnurra, som er utviklet i Trondheim (Trondheims-metoden).

Fordi man ønsket en enhetlig praksis for hele landet bestemte Helsedirektoratet $i$ et brev til helseforetakene (1) at Trondheims-metoden skal være eneste verktøy for å bestemme fødetermin og fosteralder i Norge. Vi synes prosessen har vært uryddig, og at avgjørelsen ikke er tillitvekkende begrunnet. Slik bør ikke Helsedirektoratet arbeide.

\section{Overkjører fagkunnskapen}

Norsk gynekologisk forening gjennomgikk nylig kunnskapen om aldersbestemmelse i svangerskapet og nedfelte sine anbefalinger i revidert Veileder i fødselshjelp 2014 (2). Her anbefales det at rutineultralyd gjøres i annet trimester, at svangerskapsalderen ved assistert befruktning baseres på konsepsjonstidspunktet, og at aldersbestemmelse gjort tidligere i svangerskapet ikke skal endres ved senere ultralydmålinger. Dette er helt i tråd med internasjonale retningslinjer - og begge metodene er tatt med.

Helsedirektoratet velger å se bort fra fagveilederen når de anbefaler at alle svangerskap dateres etter Trondheims-metoden i svangerskapsuke 17-19. De går således på tvers av gjeldende faglige nasjonale og internasjonale anbefalinger. I utredningsprosessen ba Helsedirektoratet om en evaluering fra Kunnskapssenteret. De kunne ikke bidra til å evaluere metodene, men henviste til en doktoravhandling utgått fra Trondheims-gruppen (3), tilsynelatende uten selv å ha gjennomgått dokumentasjonen eller den kritikken som er reist (4). Helsedirektoratet burde ha overlatt dette til fagekspertene - det hadde pasientene fortjent.

\section{Feilaktig bruk av termin for fosteralder}

Helsedirektoratet valgte seg Trondheimsmetoden eSnurra da de fant at den hadde minst skjevhet ved terminbestemmelse - i Trondheims-gruppens egen valideringsstudie (3). Gruppen brukte fosterets størrelse ved tidspunktet for rutineultralyd og antall dager igjen til fødselen i en modell som predikerer fødselstidspunktet (5). Men spørsmålet i debatten var ikke hvor bra man kunne beregne forventet tidspunkt for normal fødsel, det var å bestemme nøyaktig fosteralder, noe som er avgjørende i kliniske situasjoner gjennom hele svangerskapet.

Vil man uttale seg om fosteralder, må man vite hvor gammelt fosteret er ved tidspunktet for ultralydmålingen, hvilket Trondheims-gruppen ikke har dokumentert.

\section{«Helsedirektoratet}

ser ikke ut til å ha gjennomskuet at evalue-

\section{ringen av metodene}

\section{mot hverandre er som å sammenlikne epler \\ og pærer»}

Derimot medgir de at «Our primary focus in this paper has been on prediction of term. It is interesting to note that the approach also provides estimates for gestational age at the time of the ultrasound examination. This can be done by assuming a typical length of pregnancy of, for instance 282 days. For a given BPD or FL value, one can then subtract the predicted remaining time from the total length of 282 days and thus obtain an estimate of gestational age» (5). Men alderen bestemmes ikke ut fra svangerskapets slutt, men når det begynner.

Bergens-gruppen, derimot, gjorde nettopp dette i en prospektiv studie med internasjonalt anbefalt standard for design og analyse $(6,7)$ og laget referanseverdier for aldersbestemmelse og vekst (8-11). Studien er internasjonalt vurdert til å være blant de aller beste (12).

Men det er ikke nok for Helsedirektoratet. De foretrekker paradoksalt nok Trondheims-gruppens retrospektive populasjonsbaserte studie - der man ikke har bestemt alderen - til å bestemme alder. I Trondheim inkluderte den epidemiologiske studien 40000 svangerskap for å beregne mediant fødselstidspunkt. I Bergen inkluderte den prospektive studien 650 svangerskap for å bestemme fosteralder og vekst. Det dreier seg om forskjellige mål og metoder: Den epidemiologiske krever store tall, den prospektive, longitudinelle studien skal ikke ha høyere deltakerantall enn styrkeberegningen tilsier. Helsedirektoratet synes å være blendet av store tall og blinde for forskjellen i vitenskapelige metoder og definisjoner.

Fosteralder, fosterstørrelse, svangerskapslengde og tidspunkt for fødsel er åpenbart relatert til hverandre. Det er imidlertid ikke slik at man ved å estimere sannsynlig fødselstidspunkt automatisk kan avlede fosteralder. Bare $4 \%$ føder til beregnet termin, men skal man bestemme alderen, må man forholde seg til svangerskapets begynnelse. Helsedirektoratet viser ikke forståelse for disse forskjellene og forstår heller ikke at Trondheims-gruppen kun har evaluert terminbestemmelse (3).

\section{Overser mangler i valideringen}

Forløperen for dagens eSnurra, Snurra av 1984, var i mange år enerådende i Norge når det gjaldt aldersbestemmelse med ultralyd og terminberegning. Det var imidlertid tidlig klart at den hadde alvorlige feil når det gjaldt tiden før 17. svangerskapsuke. For eksempel måtte kvinner som kom til undersøkelse i 14. uke, returnere etter uke 17 for aldersbestemmelse. Metoden ble likevel i årevis distribuert til hele landet, uten at man gjorde oppmerksom på denne svakheten. Bergens-gruppen påpekte forholdet i 1999 og publiserte innvendinger mot metoden (13), og Norges forskningsråd ga grønt lys til å etablere nye referanseverdier for aldersbestemmelse og fostervekst.

I doktoravhandlingen utgått fra Trondheims-gruppen sammenliknes Trondheimsmetoden med Bergens-metoden, og forfatterne strekker seg langt for å vise eSnurras fortrinn (3). Trondheims-gruppen bruker sin egen populasjon, der deres metode er etablert, for å måle hvor nøyaktig terminen predikeres. Deretter bruker de samme populasjon for å teste hva Bergens-metoden gir.

En slik fremgangsmåte gir feil grunnlag for å sammenlikne metodene. Det må forventes at den terminen kvinnen har fått ved 
eSnurra, vil påvirke hennes og helsevesenets forventninger, holdninger og behandling til å konvergere mot denne prediksjonen. Og allikevel vet vi ikke noe om fosterets alder, bare om forventet termin.

Målemetodene brukt ved ultralydundersøkelse er også forskjellige: Bergens-gruppen har anbefalt hodeomkrets som førstevalg for bestemmelse av fosteralder, mens Trondheims-gruppen ikke har testet den metoden. Bergensmetoden måler fosterets lårbein som et gjennomsnitt av tre mål, mens eSnurra bruker det største av tre mål. Likevel sammenliknes de to metodene.

Trondheims-gruppen har endret antatt svangerskapslengde fra 282 dager til 283 i eSnurra (3). Dersom Bergens-metoden også var blitt testet med 283 dager, ville forskjellene i terminbestemmelse (for det var det de sammenliknet, ikke aldersbestemmelse) blitt minimal. Overtid er av Trondheims-gruppen regnet som 283 (eller 282) + 14 dager (3), noe som er feil - det skal være 294 dager eller $42+0$ uker (14).

Vi mener sammenlikningen som Trondheims-gruppen har utført, ikke er uhildet, men Helsedirektoratet ser ikke ut til å ha gjennomskuet at evalueringen av metodene mot hverandre er som å sammenlikne epler og pærer. Helsedirektoratet overser også kritikken av Trondheims-studien (4): Seleksjonsskjevheter i ukene utenom 18-20, uklare kriterier for ekskludering av fostre som kunne tenkes å være veksthemmet, og manglende redegjørelse for inkluderte fostre med avlangt hode der biparietaldiameter ble justert på basis av skallens lengdeakse.

\section{Feilaktig og ensidig vektlegging av ultralyddatering}

Det har vært et anliggende for Helsedirektoratet å få lik metode for alders- og terminbestemmelse nasjonalt, og det er gitt inntrykk av at kun bruk av rutineultralyd er løsningen. Vårt inntrykk er at det har vært vanlig blant dem som bruker Trondheimsmetoden å anvende 18-ukersrutinemålinger til å kalkulere termin og overstyre fosteraldersbestemmelser som er basert på kjent eggløsningstidspunkt, in vitro-fertilisering eller førstetrimester ultralyd. Det er blitt stillere om dette i løpet av høstens debatt, men ensidig vektlegging av rutineultralyd er utillatelig.

Følger man en slik rutine, vil de sykeste fostrene bli mest feilvurdert, da de ofte er små for alderen og blir tilregnet lavere alder ved ultralydmålingen $\mathrm{i}$ annet trimester. $\mathrm{Vi}$ mener det kan føre til kritiske feil om ikke all tilgjengelig informasjon tas med i vurderingen av fosterets alder. Hadde Helsedirektoratet lyttet til fagmiljøet i Norsk gynekologisk forening (2), kunne det blitt en mer balansert og kunnskapsbasert anbefaling.

Å legge til rette for lik behandling uavhengig av geografiske forhold er et mål vi alle støtter - dersom det er kunnskapsbasert. I dette tilfellet mener vi Helsedirek- toratet har gått utover sin kompetanse og forenklet hinsides all kunnskap.

\section{Cathrine Ebbing \\ Synnøve Lian Johnsen \\ Jørg Kessler \\ Torvid Kiserud \\ torvid.kiserud@k2.uib.no}

Svein Rasmussen

Cathrine Ebbing (f. 1967) er ph.d., overlege og postdoktorstipendiat ved Seksjon for fostermedisin, Kvinneklinikken, Haukeland universitetssykehus.

Forfatter har fylt ut ICMJE-skjemaet og oppgir ingen interessekonflikter.

Synnøve Lian Johnsen (f. 1965) er dr.med., seksjonsoverlege ved Seksjon for fostermedisin, Kvinneklinikken, Haukeland universitetssykehus. Hun har utviklet nye referanseverdier for fosteralder og vekst og er medarbeider i WHOs fostervekststudie.

Forfatter har fylt ut ICMJE-skjemaet og oppgir ingen interessekonflikter.

Jørg Kessler (f. 1970) er ph.d. og overlege ved Kvinneklinikken, Haukeland universitetssykehus. Han er hovedforfatter av kapitlet om ultralyd i svangerskapsomsorgen i Veileder i fødselshjelp (2014)

Forfatter har fylt ut ICMJE-skjemaet og oppgir følgende interessekonflikter: Han er medlem av forskningsgruppen som publiserte referansetabeller for fosterbiometri, omtalt i artikkelen.

Torvid Kiserud (f. 1944) er dr.med., overlege ved Kvinneklinikken, Haukeland universitetssykehus, og professor ved Institutt for klinisk medisin (K2), Universitetet i Bergen. Han ledet forskningen omkring ultralyd, biometri og aldersbestemmelse i Bergen og er ekstern rådgiver for WHO på området.

Forfatter har fylt ut ICMJE-skjemaet og oppgir følgende interessekonflikter: Han står bak en «konkurrerende» metode til eSnurra, som nå anbefales av norske helsemyndigheter.

Svein Rasmussen (f. 1949) er dr.med., overlege ved Kvinneklinikken, Haukeland universitetssykehus, og professor ved Institutt for klinisk medisin (K2), Universitetet i Bergen. Han bidro med dataanalyse i forskningen omkring fostervekst, størrelse og aldersbestemmelse i Bergen. Forfatter har fylt ut ICMJE-skjemaet og oppgir ingen interessekonflikter.

Litteratur

1. Brev fra Helsedirektoratet til Helse Nord RHF ref 12/6746-24. Oslo: Helsedirektoratet, 2014

2. Kessler J, Acharya G. Haugen G et al. Ultralydundersøkelse i den alminnelige svangerskapsomsorgen. https://legeforeningen.no/Fagmed/ Norsk-gynekologisk-forening/Veiledere/Veilederi-fodselshjelp-2014/Ultralydundersokelser-i-denalminnelige-svangerskapsomsorgen/ (11.1.2015).

3. Økland I. Biases in second-trimester ultrasound dating related to prediction models and fetal measurements. Doktoravhandling. Trondheim: Norges teknisk-naturvitenskapelige universitet, 2012

4. Kiserud T, Johnsen SL, Rasmussen S. Re: A direct method for ultrasound prediction of day of deli- very: a new, population-based approach. Problems of accounting for a retrospective selection. Ultrasound Obstet Gynecol 2008; 31: 225

5. Gjessing HK, Grøttum P, Eik-Nes SH. A direct method for ultrasound prediction of day of delivery: a new, population-based approach. Ultrasound Obstet Gynecol 2007; 30: 19-27.

6. Royston P, Altman DG. Design and analysis of longitudinal studies of fetal size. Ultrasound Obstet Gynecol 1995; 6: 307-12

7. Royston P. Wright EM. How to construct «normal ranges» for fetal variables. Ultrasound Obstet Gynecol 1998; 11: 30-8.

8. Johnsen SL, Rasmussen S, Sollien R et al. Fetal age assessment based on ultrasound head biometry and the effect of maternal and fetal factors. Acta Obstet Gynecol Scand 2004; 83: 716-23.

9. Johnsen SL, Rasmussen S, Sollien R et al. Fetal age assessment based on femur length at 10-25 weeks of gestation, and reference ranges for femur length to head circumference ratios. Acta Obstet Gynecol Scand 2005; 84: 725-33.

10. Johnsen SL, Wilsgaard T, Rasmussen $\mathrm{S}$ et al. Longitudinal reference charts for growth of the fetal head, abdomen and femur. Eur J Obstet Gynecol Reprod Biol 2006; 127: 172-85

11. Johnsen SL, Rasmussen S, Wilsgaard T et al. Longitudinal reference ranges for estimated fetal weight. Acta Obstet Gynecol Scand 2006; 85: 286-97.

12. Ioannou C, Talbot K, Ohuma E et al. Systematic review of methodology used in ultrasound studies aimed at creating charts of fetal size. BJOG 2012 119: 1425-39

13. Kiserud T, Rasmussen S. Terminbestemmelse ved hjelp av ultralyd - kan metoden bli bedre? Tidsskr Nor Lægeforen 1999: 119: 4331-4.

14. Morken N-H, Haavaldsen C, Heimstad R et al. Overtidig svangerskap. https://legeforeningen.no/ Fagmed/Norsk-gynekologisk-forening/Veiledere/ Veileder-i-fodselshjelp-2014/Overtidigsvangerskap/ (20.2.2015).

Mottatt 20.1. 2015, første revisjon innsendt 9.2. 2015, godkjent 27.3. 2015. Redaktør: Lise Mørkved Helsingen.

Publisert først på nett. 